Univerzitet u Beogradu
Poljoprivredni fakultet
Institut za poljoprivrednu tehniku
Naučni časopis
POLJOPRIVREDNA TEHNIKA
Godina XLV
Broj 2, 2020.
Strane: $67-78$

\title{
IRRIGATION SYSTEM BASED ON ARDUINO UNO MICROCONTROLLER
}

\author{
Mohanad Abdulhamid ${ }^{* 1}$, Kimani Njoroge ${ }^{2}$ \\ ${ }^{1}$ AL-Hikma University, Iraq \\ ${ }^{2}$ University of Nairobi, Kenya
}

Abstract: In crop production, a healthy water balance is essential for high quality yields. Under-watered crops suffer from nutrient deficiencies while over-watered plants are more susceptible to diseases pressure and can in some cases lead to root death through suffocation. Also over-watered plants are not able to withstand dry spells during dry season. The aim of this paper is to use control engineering principles and concepts to provide a microcontroller based irrigation system. The system helps in saving money and water and at the same time increasing crops production. The automated irrigation system is controlled using ATmega328 microcontroller based on Arduino platform. The system is programmed via the microcontroller to give interrupt signal to the irrigation system (drip, sprinkler, ditch etc.) depending on the soil moisture levels. The soil moisture/humidity levels are checked using soil moisture sensor. Whenever there is a change in moisture/humidity in the soil, this sensor senses the change and gives an interrupt signal to the micro-controller and thus the watering system is activated or deactivated.

Keywords: Irrigation system, microcontroller

\section{INTRODUCTION}

\subsection{Brief Background}

The continuous increase in food demand requires a rapid improvement in food production technologies.

"Corresponding Author. E-mail: moh1 hamid@yahoo.com 
Food insecurity is a major challenge in developing countries. In those countries where the economy is mainly agriculture based, use of technology to improve on yields is paramount.

Agriculture in some countries is mainly rain fed. Global warming has led to climate changing thus rendering the rain fed agricultural systems unreliable. This has resulted on more land being put under irrigation to meet the food demand for the growing population.

In Kenya for example, approximately 125,000 hectares of land is under irrigation out of the estimated potential of 1.3 million hectares. Only $30 \%$ of the 1.3 million hectares potential irrigation land has available water resources while the other $70 \%$ require water harnessing for irrigation to be realized.

Irrigation is the process of artificial application of water to land to aid crops growth. It is mainly used during dry seasons or in dry areas where rainfall is scarce.

\subsection{Types of Irrigation}

\subsubsection{Ditch Irrigation}

This is one of the earliest irrigation methods to be used. Ditches/trenches are dug out and crops are planted along the ditches in rows.

\subsubsection{Terrace Irrigation}

The land is shaped into steps. Crops are planted on the flat areas. Water flows down the steps watering each of the flat areas. This method is both time and labor intensive in building the terraces.

\subsubsection{Drip Irrigation}

This is one of the most effective and efficient method of irrigation as water is dripped at the crop root zone. The method saves water from runoff and evaporation.

\subsubsection{Sprinkler Irrigation}

This method uses overhead sprinklers. Each sprinkler irrigates a given area. During installation care should be taken to avoid over or under watering some areas. If poorly installed a lot of water is wasted via runoff.

\subsubsection{Rotary Systems}

This is an improvement of sprinkler irrigation method where sprinklers are mechanically moving in a rotary/circular manner. This method is best suited for huge tracks of land. This method is more efficient than the basic sprinkler method.

This paper presents a microcontroller based irrigation system which monitors and controls the soil moisture content so as to optimize the application of water. Good water balance leads to maximum crop production.

The system presented automates irrigation systems with the use of low cost sensor, microcontroller and the simple circuitry, thereby making it a low cost. Some works related to the topic of this paper can be found in literatures[1-5]. 


\section{2- Design and Implementation}

The system has three major units; humidity sensing unit, control unit and the output unit. The soil humidity is detected using YL-69 soil sensor (a resistance type sensor). The control unit is achieved using ATMega328 microcontroller based on Arduino platform. The output of the control unit is used to control the irrigation system by switching it on and off depending on the soil moisture contents. Two stages of design are undertaken; hardware and software.

\subsection{Hardware Design}

\subsubsection{Control Unit: ATMega328 microcontroller on Arduino platform}

ATMega328 microcontroller on Arduino platform is selected the control unit of the microcontroller. Arduino Uno shown in Fig.1 is selected from the expansive Arduino family. Arduino Uno has a total of 20 inputs pins of which 14 are digital and 6 are analog inputs. The digital pins can be used as either inputs or outputs and also 6 of the 14 pins can be utilized as pulse width modulation (PWM). The board has a $16 \mathrm{MHz}$ ceramic resonator, a universal serial bus (USB) connection and a power jack.

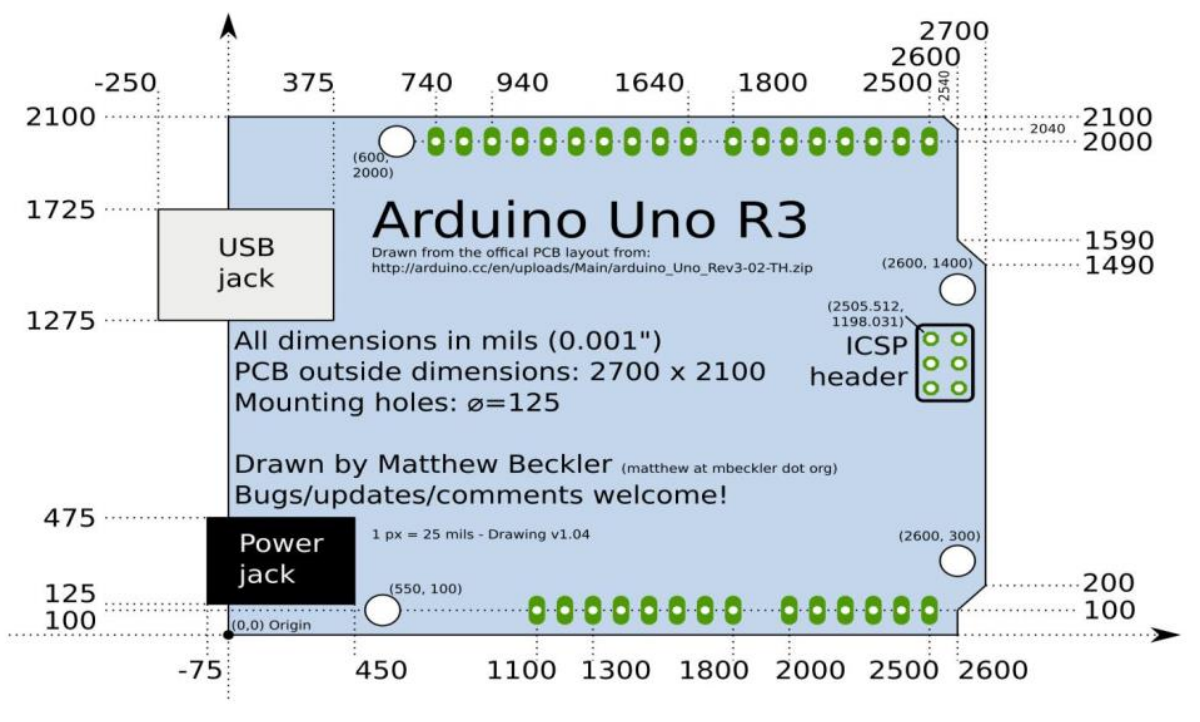

Figure 1. Arduino Uno

In the design of the system, analog pins are selected as the Arduino input and digital pin is selected as the Arduino output pins. Other important pins on the Arduino board are shown in Table 1. 
Table 1. Important pins in Arduino

\begin{tabular}{|l|l|}
\hline AREF & Analog Reference pin \\
\hline GND (Digital side) & Digital Ground \\
\hline Vin & Input voltage (external power source) \\
\hline $5 V$ & Regulated power to the microcontroller \\
\hline $3.3 V$ & $3.3 V$ generated by the on-board FTDI chip \\
\hline$G N D$ & Ground \\
\hline
\end{tabular}

The pins on the Arduino are selected as shown in Table 2.

Table 2. Selected pins on Arduino

\begin{tabular}{|c|c|}
\hline Pin & Connections \\
\hline Digital pin 2 & $L C D$ D7 pin \\
\hline Digital pin 3 & LCD D6 pin \\
\hline Digital pin 4 & $L C D$ D5 pin \\
\hline Digital pin 5 & $L C D$ D4 pin \\
\hline Digital pin 11 & LCD Enable \\
\hline Digital pin 12 & LCD RS pin \\
\hline Digital pin 7 & Connection to Water Pump \\
\hline Digital pin 8 & LED Pin indicating Soggy soil \\
\hline Digital pin 9 & LED Pin indicating Moist soil \\
\hline Digital pin 10 & LED Pin indicating Dry soil \\
\hline Analog Pin 4 & Connection to Soil Moisture Sensor \\
\hline$V C C$ & $5 V D C$ \\
\hline GND & Ground \\
\hline
\end{tabular}




\subsubsection{Sensing Unit}

\subsubsection{YL-69 soil moisture sensor connection to Arduino}

YL-69 soil moisture sensor is interfaced to the Arduino through a digital printed board circuit(PCB) drive. The PCB drive has a digital potentiometer and a LM393 comparator. The LM393 comparator is used to compare the voltages across the sensor probes and the set Vcc voltage. The digipot is used to alter the sensitivity of the sensor when connected in digital mode. The out of the PCB drive has four connections pins as shown in Table 3.

Table 3 YL-69 PCB pins

\begin{tabular}{|l|l|}
\hline$V c c$ & Connected to 5VDC \\
\hline$G N D$ & Connected to ground \\
\hline$A O$ & Analog value output connector \\
\hline$D O$ & Digital value output connector (O or 1) \\
\hline
\end{tabular}

The analogue configuration is selected as its more stable compared to the digital configuration. The PCB drive pin A0 is connected to the Arduino analog pin A0. Fig.2 shows YL-69 connection to Arduino board.

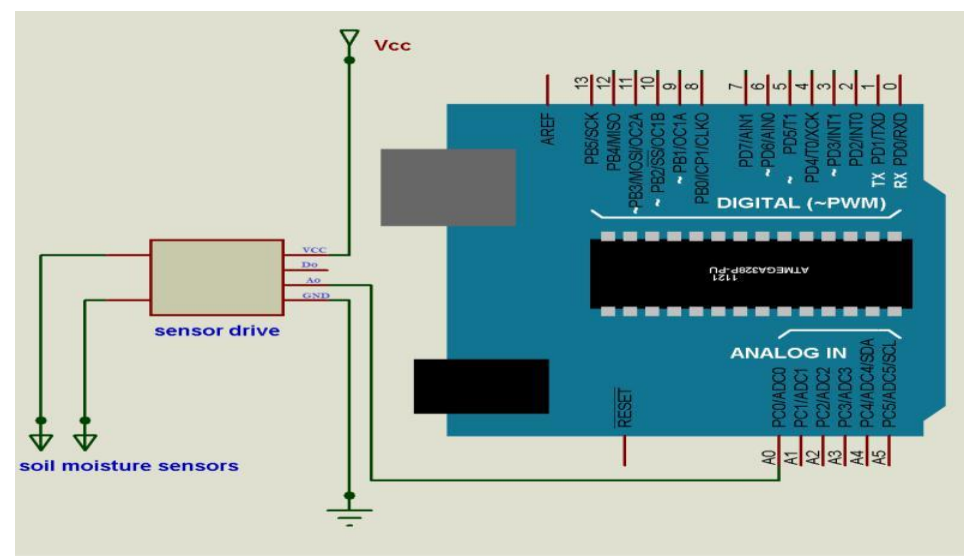

Figure 2. YL-69 Connection to Arduino board

The output of the sensor to the Arduino analog pin A0 is resistance. The resistance to flow of current between the sensor probes changes with soil moisture level and soil type. The current passing through the sensor probes $\left(\mathrm{I}_{\text {out }}\right)$ for different soils and different soil moisture levels is calculated as shown below:

$$
\mathrm{I}_{\text {out }}=\mathrm{Vcc} /\left\{\text { soil resistance value }\left(\mathrm{R}_{\mathrm{S}}\right)\right\}
$$




\subsubsection{Output Unit}

\subsubsection{LCD interface with Arduino}

To affect display, a 16x2 Liquid Crystal Display (LCD) is chosen. LCD pins D4, D5, D6 and D7 are used as data lines in a 4-bit mode configuration. These pins are connected to Arduino pins 5, 4, 3 and 2 respectively. Pin 15(A) is connected to Vcc and pin $16(\mathrm{~K})$ is connected to GND. These pins (A and $\mathrm{K}$ ) are for the light emitting diodes(LEDs) integrated on the LCD circuit board. LCD's pin E (Enable) is connected to digital pin 11 on the Arduino board. Pin RS (Register Select) on the LCD is connected to Arduino digital pin 12. R/W pin of the LCD is connected to GND (ground). Fig.3 shows the LCD-microcontroller interface.

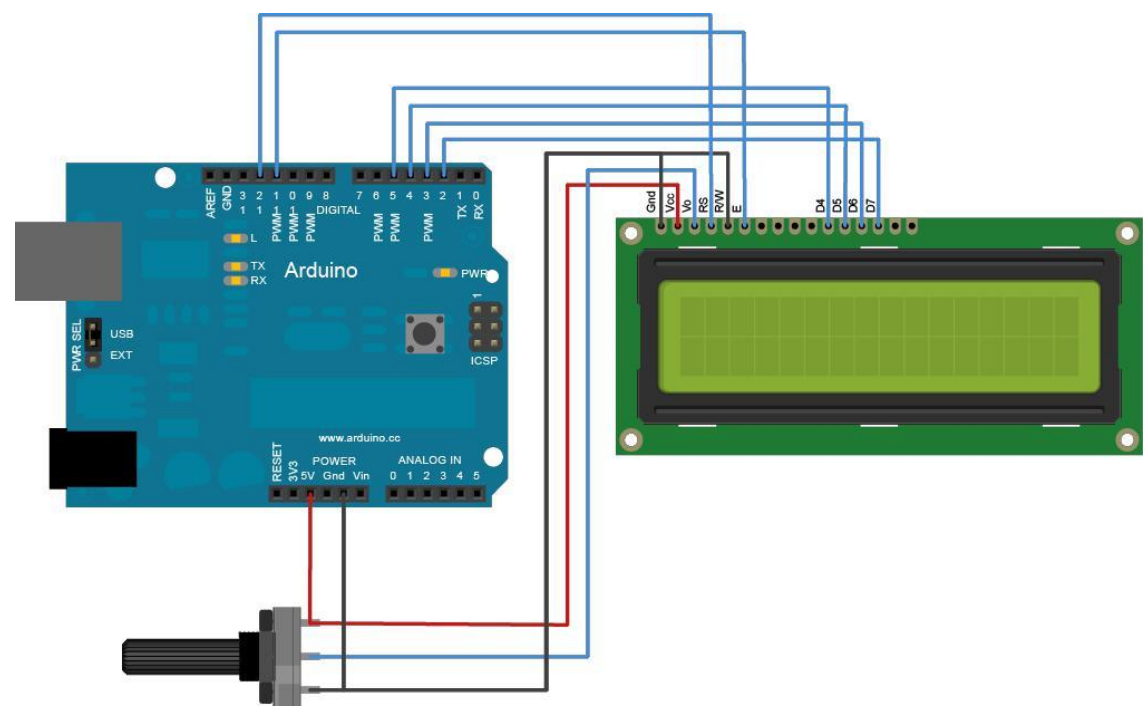

Figure 3. LCD Connection to Arduino board

\subsubsection{Light Emitting Diodes(LEDS)}

To indicate the three states of the soil, three LEDs are used. The three LEDs lit up depending on the soil moisture content. When the soil is dry, LED connected to Arduino digital pin 13 is lit. For moist soil (required condition), LED connected to Arduino digital pin 12 lit up and for soggy soil, LED connected to Arduino digital pin 11 lit up. The three LEDs are connected to the microcontroller as shown in Fig.4. 


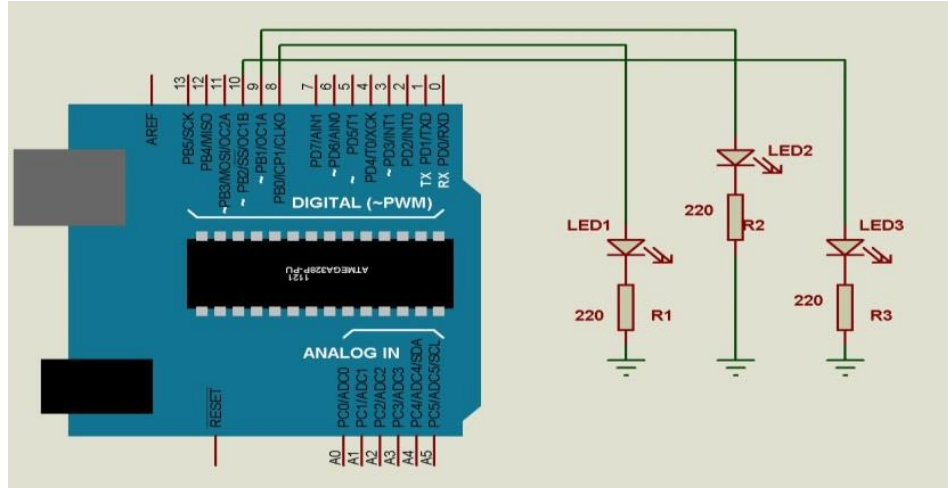

Figure 4. LEDs Connection to Arduino board

Ohms law is utilized to determine the size (in ohms) of the protection resistor to be interfaced with the LEDs. From Ohms law

$$
\text { Voltage }(\mathrm{V})=\{\text { Current }(\mathrm{I})\} *\{\operatorname{Resistance}(\mathrm{R})\}
$$

Where as in our case;

$\mathrm{V}=\mathrm{Vcc}(5 \mathrm{~V})$-Voltage drop across LED (selected LEDs has 2.0V)

$\mathrm{I}_{\mathrm{LED}}=\mathrm{LED}$ current $(20 \mathrm{~mA})$

$\mathrm{V}_{\mathrm{LED}}=\mathrm{LED}$ Voltage drop (red in colour) $(2 \mathrm{~V})$

$\mathrm{R}=$ minimum required resistance value

Therefore

$$
\mathrm{R}_{\min }=\{(5-2) \mathrm{V}\} /\{20 \mathrm{~mA}\}=150 \Omega
$$

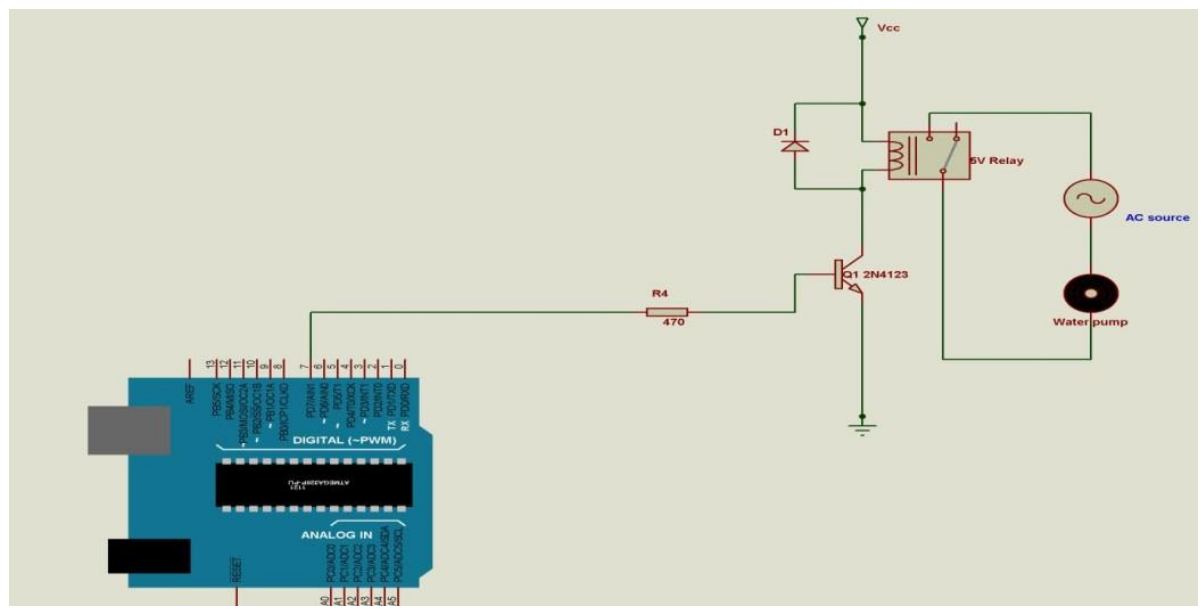

Figure 5. Relay interfacing of Arduino to the 240 VAC pump 
To achieve current limitation a resistance value higher than the calculated $R_{\min }$ is selected. A $220 \Omega$ resistor is used and thus only $13.6 \mathrm{~mA}$ current is allowed to pass through each of the three LEDs.

\subsubsection{Water Pump Connection to the Arduino}

To implement the final bit of the automated irrigation system, an electric motor (240VAC) is selected as the water pump. The first two units of the system i.e. sensing unit and the control unit (microcontroller) are powered by 5VDC. To interface the two units, a 5VDC relay (SLT73-5D-1Z) is used as the isolation unit.

The microcontroller is connected to the relay via an NPN transistor (2N4123). To protect the transistor; while turning it on, a resistor is used. The resistor limits the current flowing through the transistor. As is the case with LEDs, ohms law is used as shown below.

$$
\mathrm{R}_{\min }=(5-0.7) \mathrm{V} / 40 \mathrm{~mA}=107.5 \Omega
$$

A resistor of $470 \Omega$ is selected and thus the current through the transistor is limited to;

$4.3 \mathrm{~V} / 470 \Omega=9.12 \mathrm{~mA}$

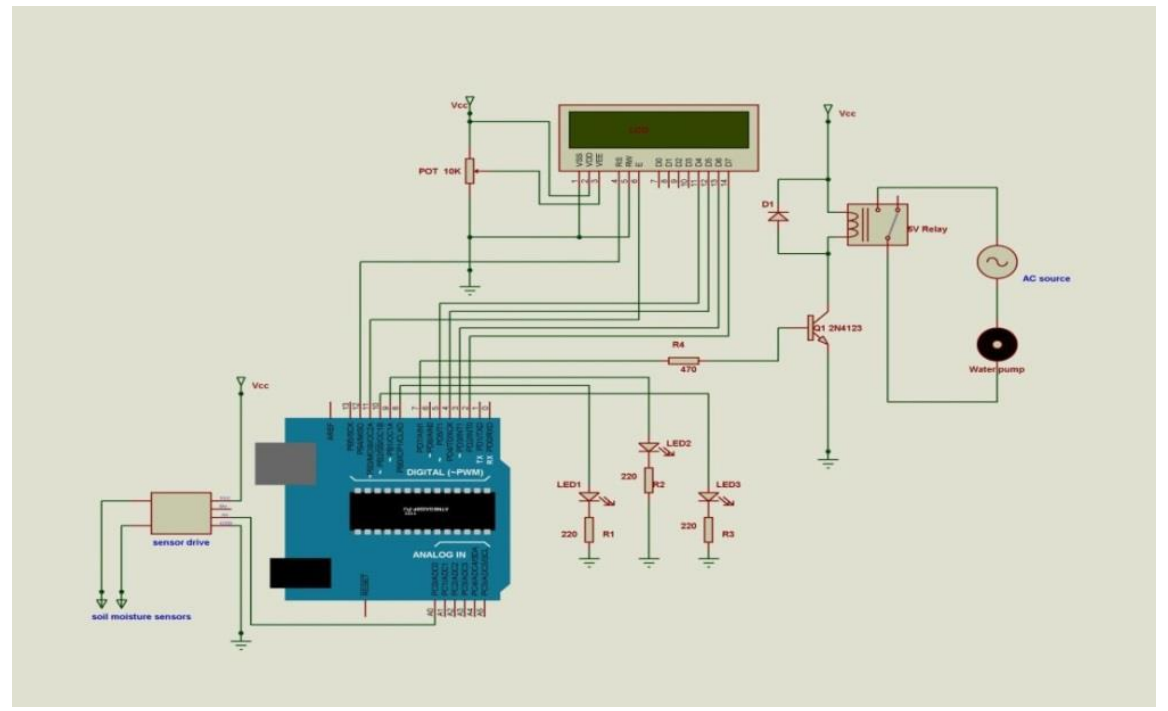

Figure 6. Circuit with all the components and parts

To protect the microcontroller from back e.m.f during switching, a diode is connected across the relay. The connection is as shown in Fig.5. The complete design is shown in Fig.6 


\subsection{Software Design}

To be able to interpret the different states of the soil as prompted by the soil sensor, the microcontroller is programmed. The Arduino integrated development environment (IDE) is used. The idea is based on $\mathrm{C}++$ and thus can be extended using $\mathrm{C}++$ libraries. Arduino programs (sketches) are cross platform, simple, clear and at the same time flexible for advanced programmers.

\subsubsection{Program Pseudo Code}

The instructions of program pseudo code are given below, while, Fig.7 shows the flowchart

READ sensorvalue

COMPARE sensorvalue with set threshold

IF sensorvalue > maximum set value TURN-ON pump

DISPLAY soil condition on LCD

LIGHT dry soil LED

ELSE IF sensorvalue < maximum set

value $>$ minimum set value TURN OFF pump

DISPLAY soil condition on LCD

LIGHT moist soil LED

ELSE IF sensorvalue < minimum set value TURN-OFF pump

DISPLAY soil condition on LCD

LIGHT soggy soil LED

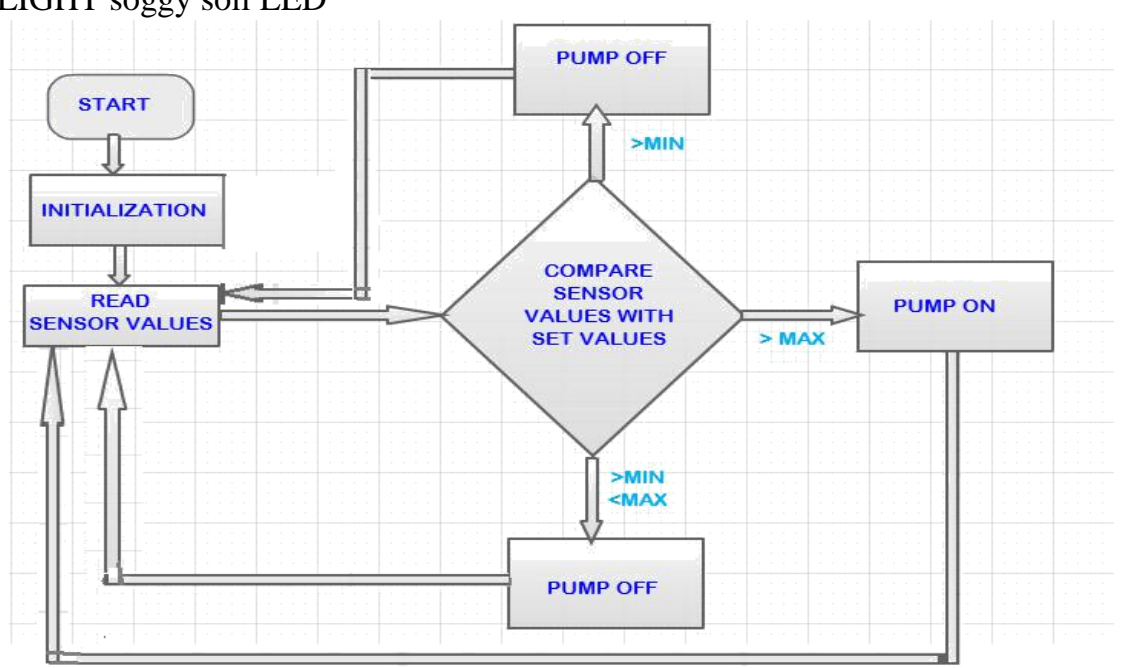

Figure 7. Flow chart 


\section{RESULTS AND DISCUSSION}

\subsection{Results}

The volumetric water content (VWC) of sand soil, red soil and black soils are calculated. The raw data collected from the soil moisture sensor is recorded as shown in Table 4. The soil is measured in equal amount of $250 \mathrm{~g}$. Water is added in the soils in steps and the sensor values recorded.

Table 4. Sensor values

\begin{tabular}{|c|c|c|c|}
\hline Soil water content $(\mathrm{cm} 3)$ & \multicolumn{3}{|c|}{ Sensor Reading } \\
\hline 0 & Loam soil & Sand soil & Red soil \\
\hline 50 & 1021 & 1022 & 1020 \\
\hline 75 & 580 & 546 & 781 \\
\hline 100 & 360 & 234 & 568 \\
\hline 125 & 237 & 243 & 295 \\
\hline 150 & 203 & 184 & 274 \\
\hline 175 & 191 & 180 & 235 \\
\hline & 180 & 170 & 220 \\
\hline
\end{tabular}

\subsection{Discussion}

The data obtained from the sensor reading and recorded in Table 4 is used to plot a graph of soil water content against sensor reading as shown in Fig.8.

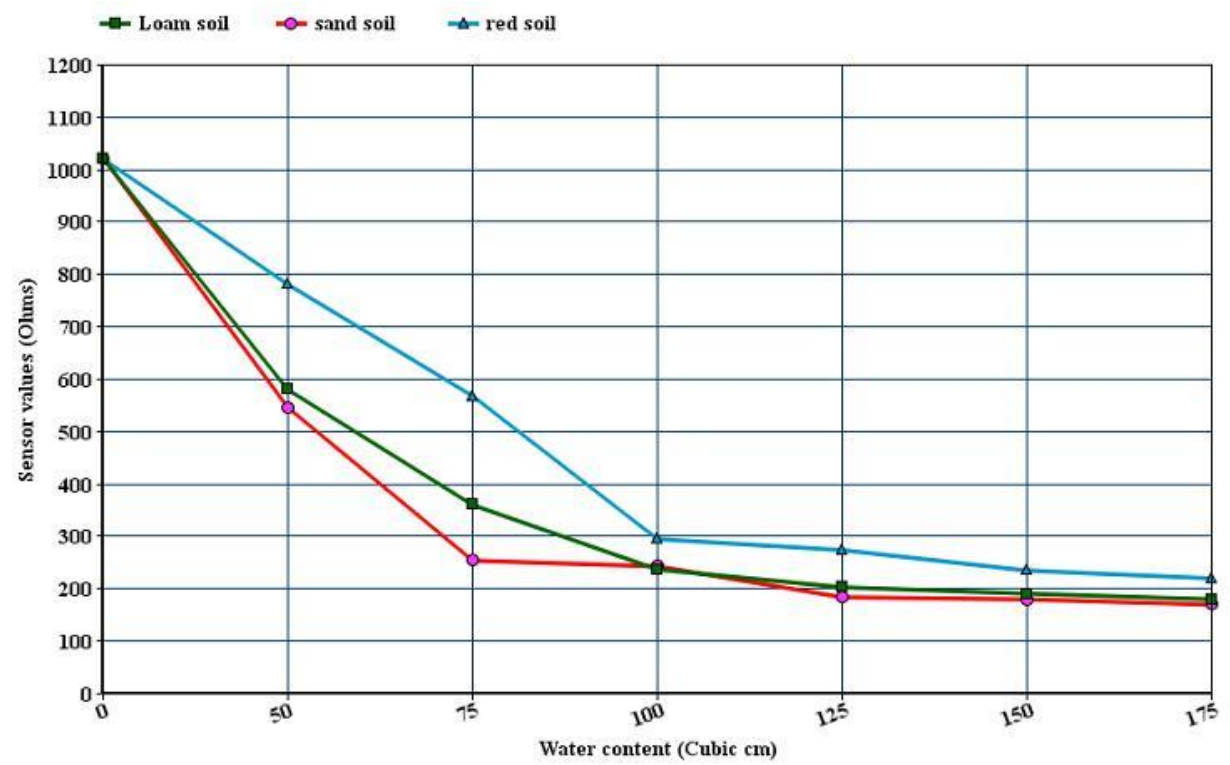

Figure 8. Sensor reading against water content 
The soil moisture sensor (SMS) and (YL-69) used is a resistance sensor type. Its output is the resistance in the soil between the two SMS probes. The obtained graph is an exponential one. The value of the soil resistance decreases with increase in water content to a certain point.

To come up with the results, the three soils are dried using a frying pan until all the moisture content is lost. 250 grams is measured for the red soil, black soil and the sand soil. Water is added in steps of $25 \mathrm{~cm}^{3}$ and sensor value recorded.

The value of soil sensor at dry soil is almost equal for the three soils at 1021, 1022, 1020 for black soil, sand soil and red soil respectively. On adding $50 \mathrm{~cm}^{3}$, the resistance value reduced drastically to the range of 500. On adding more water the resistance value kept reducing.

At around $100 \mathrm{~cm}^{3}$, of water the reduction on the soil resistance stated reducing at a much lower rate. This is because at this point the soil is now becoming saturated with water and thus adding more water has a small effect on the soil resistance.

The sensor is calibrated and three states defined. The states are soggy, moist and dry. When the dry state is achieved, the control unit (microcontroller) switched the water pump on via a relay circuit. The three states are indicated using three different LEDs and an LCD. The LCD also indicated when the pump is running.

The control circuit and the sensor circuit are powered using a $9 \mathrm{~V}$ alkaline battery which is connected via a voltage regulator with an output of $5 \mathrm{~V}$.

\section{CONCLUSION}

A system to monitor moisture levels in the soil was designed. The system was used to switch on/off the watering system/pump according to set soil moisture levels. The control unit was implemented using a microcontroller on Arduino platform while the sensing bit was implemented using a SMS YL-69. Three LEDs and an LCD were used to implement the display of the three soil states i.e. soggy soil, moist soil and the dry soil states. To switch between the control and the irrigation systems, a relay switching circuit was used.

\section{BIBLIOGRAPHY}

[1] Kimani Njoroge. 2011. Microcontroller based irrigation system. B.Sc. Graduation Project, Nairobi University, Kenya.

[2] S. Mahendra, and M. Laksmana Bharathy. 2013. Microcontroller Based Automation of Drip Irrigation System. J.of Science \& Technology. Vol.2. Issue 1. pp.1-6.

[3] S. Pasha, and B. Yogesha .2014. Microcontroller based automated irrigation system. The International Journal of Engineering and Science. Vol.3, Issue 7. pp.6-9.

[4] R. Kowsalya, and M. Karthigha, 2015. A survey on microcontroller based intelligent irrigation system. International Journal of Emerging Technology in Computer Science \& Electronics. Vol.19. Issue 1., pp.83-86,

[5] B. Kumar, P. Srivastava, R. Agrawal, and V. Tiwari. 2017. Microcontroller based automatic plant irrigation system. International Research Journal of Engineering and Technology. Vol.4, Issue 5. pp. 1436-1439. 


\title{
IRIGACIONI SISTEM KONTROLISAN SA ARDUINO UNO MIKROKONTROLEROM
}

\author{
Mohanad Abdulhamid ${ }^{1}$, Kimani Njoroge ${ }^{2}$ \\ ${ }^{1}$ AL-Hikma University, Iraq \\ ${ }^{2}$ University of Nairobi, Kenya
}

Sažetak. U ratarskoj proizvodnji dobar balans (raspored) vode je neophodan za prinose visokog kvaliteta. Usevi koji nisu snabdeveni potrebnom količinom vode navodnjavaju se i zbog nedostatka hranjivih sastojaka, ali suviše navodnjavane biljke su podložne pritisku i pojavi bolesti i mogu u nekim slučajevima dovesti do propadanja korena biljke zbog gušenja. Takođe, prekomerno navodnjavane biljke ne mogu kasnije da izdrže posledice sušne sezone.

Cilj ovog rada je korišćenje inžinjerskih principa i koncepta za kontrolu sistema za navodnjavanje upotrebom određenog mikrokontrolera. Sistem pomaže u uštedi vode i novca i tako istovremeno značajno povećava proizvodnju, prinos useva.

Automatski sistem za navodnjavanje se kontroliše i upravlja sa mikrokontrolerom tipa ATmega328 koji je zasnovan na osnovu otvorene platforme Arduino Software .

Sistem se programira sa mikrokontrolerom kako bi sistem za navodnjavanje (kapljači, rasprskivači, itd.) dobio potreban signal koji zavisi od sadržaja vlage zemljišta.

Sadržaj vlage u zemljištu se proverava pomoću senzora za vlagu u zemljištu i kada dođe do promene vlažnosti zemljišta, ovaj senzor registruje vrednost promene i šalje odgovarajući prekidni signal mikrokontroleru ATmega328 koji sistem za navodnjavanje (pumpe) aktivira ili deaktivira.

Ključne reči: Sistem za navodnjavanje, mikrokontroler.

Prijavljen:

Submitted:

15.07.2019.

Ispravljen:

Revised:

10.02.2020

Prihvaćen:

Accepted:

12.02.2020. 